\title{
Land System Reform in Urbanization Process
}

\author{
Xin Yang \\ School of Literature, Law and Economics \\ Wuhan University of Science and Technology \\ Wuhan, China
}

\begin{abstract}
The so-called urbanization refers to the process that farmers occupying most of the population in agricultural society change occupation and migrate place of residence. Land plays a pivotal role in it. It is the reason that our country focuses on researching land issues through the years. This article firstly analyzes mode of economic growth in China, finds out disadvantages of existing land pattern and then discovers growth potential of Chinese economy, takes land system reform as the breakthrough to discuss problems and measures of land system reform related to the urbanization process.
\end{abstract} reform

Keywords-urbanization; Chinese economy; land system

\section{INTRODUCTION}

Thinking errors of Chinese economic growth and urbanization mode.

Wrong judgment comes from wrong theory and improper observation of realistic society.

- Land finance means confiscating land at low price and selling land at high price. This statement is very inaccurate, because about half of the land, for land of industrial development area is sold at a low price, even losing money. Although in land acquisition, the compensation for farmers is relatively low, infrastructure shall be constructed. After the infrastructure is perfect and industrial development zone is found, the land is transferred to maker of industrial land at the price less than cost. Therefore, commercial and residential land can make profit. Local government often limits the quantity and offers fewer commercial and residential lands but offer more industrial lands. So it is incorrect to say that land finance means confiscating land at low price and selling land at high price.

- The Rigid Demand of Urbanization Leads to the Situation That the Housing Price Raises Unceasingly. The urbanization level in China is relatively low and many people want to go into town in the future, so it is reasonable for rise of housing price in cities. However, among 200,000,000 peasantworkers in China, there are only less than $1 \%$ of them who can afford commercial residential buildings in cities. [1] Therefore, the sharp rise of housing price cannot be the rigid demand of urbanization but

* Xin Yang, Master candidate of Wuhan University of Science and Technology. because some factors hype the real estate.

- Labor Shortage Begins To Appear In China. In recent years, the salary of low-grade labor force in cities begins to appear rapid increase. It shows that there are not too many surplus labors in the countryside. This is Lewis Turning-Point mentioned in economics. Rural areas cannot produce labor force, so salaries must be increased to absorb more labor force in rural areas. At present, the urbanization rate in China is only $54.77 \%$. The proportion of pure agricultural labor force in China is $35 \%$. GDP of agriculture only occupies $10 \%$ of the total GDP. [2] It means that the productivity gap and income gap between urban and rural areas are more than three times, which show that there are still many surplus labors in the countryside.

The above examples only explain some problems that worth discussing in economic growth of China. Only through understanding economic development model in China can we know about Chinese urbanization and then put forward measures to promote the process of new-type urbanization.

\section{ECONOMIC GROWTH PATTERN IN CHINA}

1) East Asian Model: Economic entities such as Japan, South Korea, Taiwan, even Singapore and Hong Kong are called East Asian Model in economic development process, namely high investment, high saving rate and high dependency level on export. [3] However, China Model is an extreme version of East Asian Model. That is to say, China mainly relies on investment with lower domestic demand. Local governments in China show extremely strong desire even difficult to be satisfied for investment and economic growth, especially development and introduction of exportoriented manufacturing industry, which can truly distinguish "China Model" from the recognized "East Asian Model".

2) Consequence of the current developing mode in China.

a) In order to digest surplus productivity in manufacturing industry, the government must officially lower RMB exchange rate.

b) Induce international investors to think that RMB will be forced to increase in value finally and invest a large number of hot money, which will inevitably lead to substantial growth of foreign exchange reserve.

c) In order to eliminate drawbacks brought by hot money, the Central Bank is forced to issue excessive RMB to 
hedge. The consequence is that serious excess currency liquidity appears in economy.

3) Consequences caused by excess liquidity.

a) Large sum of money will be poured into commercial and residential land with a small amount of supply because of monopoly of local governments, which leads to soaring and excessively high real estate.

b) A large number of farmland occupation, land-lost farmers, social contradictions and mass disturbances.

c) Environmental damage, ecological capital loss and excessive carbon emission.

d) Insufficient protection of labors' right, let alone household registration reform.

The above problems can be explained logically as follows: Industrial land is transferred at low prices. The appreciation of RMB exchange rate is not timely, which lead to rapid increase of foreign exchange reserve, excess liquidity in economy. Excess floating currency can supplement high price of commercial and residential land with small amount of supply from local governments. Therefore, for real estate bubble in China, the requirement for real estate is very large, which has relationship with low price transferring of industrial land. The supply is few. It relates to monopoly and small amount of supply of commercial and residential land. It is the problem of land system. Coastal cities and inland cities, big cities and small cities in China are building national, provincial, prefecture level, county level and township level development zones. Sometimes a town builds several development zones. It must have relationship with land acquisition system of our country.

\section{LAND POLICY TOOLS AND CHINESE DEVELOPMENT MODEL}

\section{A. Fiscal Incentives in Land Transfer}

In the process of inviting investment, local governments face investors of two different properties. The first kind is manufacturing and industrial investors. The second kind is investors of tertiary industry including commercial and real estate development. [4]

However, manufacturing enterprises lack location characteristics. Most of them do not manufacture for local consumers, but manufacture tradable goods for consumers of other regions and countries. Service industry is just the opposite. Manufacturing sectors lack location characteristics, which lead to the situation that industrial land forms an extensive buyer's market in the process of inviting investment in many places. But lands for service industry are regional in each city and it is specific seller's market. Local governments can transfer lands at high price by ways of "bidding, auction and listing", and transfer high price of land to consumers of local housing market. Therefore, local governments supply large quantities of industrial lands with low price but annually control the scale in supplying commercial and commercial lands through land reserve center. They transfer lands of manufacturing industry and slash the price. [5]

\section{B. Differentiation Strategy of Land Transfer}

The benefits acquired by local governments in investment competition of manufacturing industry come from revenue produced in manufacturing industry, as well as incomes such as related business tax and transfer fee of commercial and residential lands brought by promotion of manufacturing industry development for economic growth of local service industry. It can be called "Spillover Effect" brought by development of manufacturing industry. Local governments universally think manufacturing industry will greatly promote the growth of local service industry.

\section{Land Finance}

Local governments use land as policy tool to open up fiscal revenue sources in budget (revenues of manufacturing industry and service industry) and beyond budget (land-transferring fees), and adopt strategies to maximize finance through actions such as provide large quantities of industrial land at low price and limit the quantity of commercial and residential lands and transfer them at high price in regional competition.

The results caused by land finance include: from 2009 to 2013 , the annual growth rate of urban population in China is $3.17 \%$, while the growth rate of built-up area in cities reaches up to $6.3 \%$, and the annual growth rate of urban construction land area is $7.6 \%$. [6] The speed of urbanization of population is obviously slower than that of urbanization of space. The great leap forward of urbanization of space brings serious imbalance of land-use structure and real estate bubble: there are excessive industrial lands and the government limits the quantity of commercial and residential lands.

The usage rate of lands in most cities especially in industrial development zones of our country is extremely low. Even though in developed areas, the plot ratio of industrial land is only 0.35 to 0.65 . The investment intensity of large number of industrial land is only several hundred thousand yuan per mu. The standard of urban planning in countries all over the world is that the area of industrial land does not exceed 10 to $15 \%$ of urban lands, no more than $20 \%$ at most. While in our country, it exceeds $40 \%$ in general.

The above land transfer patterns lead to the situation that the "urbanization of population" seriously mismatches with "urbanization of space". The unlimited sprawl of cities wastes precious agricultural lands. Meanwhile, great proportions of lands transferred are not used for residential lands that people need most.

\section{SUSTAINABILITY OF GROWTH DEPENDS ON EFFECTIVE REFORM}

Excessive construction of unordered projects, overlapping investment and bubble appear in infrastructure construction, high-end residential market, commercial residential building and emerging industry, excess production capacity of manufacturing industry lead to the situation that the investment cannot be turned into profits, and bad debts in banks and government debts rise. It will inevitably cause retardation of fixed investment. China's economic development faces the risks of hard landing in the medium term. The occurrence of 
hard landing risk depends on whether effective transformation can be realized or not. The government intends to reverse unsustainable and unscientific development pattern, take the road of new urbanization and stop real estate bubble. The socalled Scientific Outlook on Development is to realize scientific and sustainable development and citizenization of peasant-workers.

Different from comprehensive reform, effective reform refers to find breakthrough of reform under the premise of understanding Chinese development model and mechanism and let the last reform create conditions for the next reform. Meanwhile, it shall consider the initial condition of economic distortion.

\section{A. Development Potential of Urbanization}

At present, the per capita income of China is equivalent to that of $10 \%$ in America. The official urbanization including floating population is just over $50 \%$. The proportion of registered population is only $35 \%$. More than 200,000,000 peasant-workers do not have registered permanent residence. This is one of the advantages of China. It shows that the urbanization has great potential. However, under relatively low urbanization level, serious real estate bubble has appeared. It hinders permanent migration of large number of floating population in urbanization process, because these people cannot afford even rent a decent house in cities. There are $35 \%$ of labor forces taking up an occupation in rural areas. They have the potential of transformation. However, excessively high housing price and household registration system in cities make the price of labor forces increase rapidly when there are a large number of surplus labor forces in the countryside of China. Low-end labor forces cannot effectively transfer from rural areas to cities. It directly damages the competitiveness of China.

\section{B. Monopolistic State-Owned Sectors Also Have Relatively Large Potential}

Such as heavy chemical industry in upstream-petroleum, petrifaction, electric power, resource exploitation; public utility - power grid, urban infrastructure, water, gas, electricity and garbage disposal; middle end and high end service industry-telecommunications, finance, insurance, transportation, education and healthcare industry [7]. If the government can establish feasible mechanism, let excess liquidity enter monopolized industry to form effective capital input and increase competition, lower price and create employment opportunity, the economic growth in China will have potential as well. However, state-owned sectors monopolize these industries to some extent. It is very difficult to break the monopoly. But if the monopoly is not broken, it is impossible for economic growth in China to keep high growth rate.

In reality, at present, it is in urgent need of reform, such as break monopoly, land, housing, census register and financial system reform. It is similar to the situation that a slight move in one part may affect the situation as a whole. It is also difficult to reconstruct interest pattern.

\section{BREAKTHROUGH OF REFORM}

Land system reform: Reformation of land requisition system and commercialization of collective building land are two sides of a coin. The government does not confiscate land and become single main part of land supply. Collective building land allows farmers in suburban areas to supply lands for the market. It means that this part of land will not become state-owned through expropriation.

\section{A. The First Breakthrough of Reform}

Urbanization-land-finance and taxation-reform of household registration system. The key is to make the most of market mechanism to adjust and increase supply quantity of urban housing. When resolving the situation that the real estate control of central government at present is in dilemma and effectively promoting economic growth, gradually eliminate real estate bubble in cities and create stable, long-term and sustainable tax base for local governments. At present, the real estate regulatory policy of the central government is in dilemma. If the government does not adjust and control further real estate bubble and continuously control real estate, it may promote further economic downturn. So it is necessary to adjust policy thinking. Under the circumstances of avoiding real estate bubble and preventing collapse of real estate market, solve housing and education problems appearing in the situation that large quantifies of floating population enter cities for permanent settlement, stimulate domestic demand through these ways and promote economic growth.

Concrete actions: (1) "Zonal expropriation". Make use of market mechanism and allow local farmers to legally build rental housing for external population. (2) The government confiscates a small percentage of lands of local farmers for free. Some are used to build infrastructure in urban villages. The rest of the land is sold for financing of infrastructure. The government can solve problems in land use and financing of infrastructure in cities and suburbs without using financial funds and reserve some lands for farmers. [8] (3) Flexibly use planning measures, properly increase floor-area ratio of privately owned land of farmers and ensure effective appreciation of privately owned lands of villagers. Encourage local farmers to build rental housing, which can save the investment of security housing, solve housing problem of most floating population and improve property income of residents in cities and suburbs.

The above measures need gradual promotion according to planning to avoid overlarge impact on housing price in market at present. At the meantime, it also sends signals for speculators of real estate speculation that "the real estate speculation has no future". Then the government can comprehensively cancel real estate regulatory policies to activate real estate market and prevent further rise of housing price.

\section{B. The Second Breakthrough of Reform.}

Rural land consolidation commutes construction land index and realize agricultural modernization and urban-rural integration through farmland ownership affirmation. The rural land consolidation shall be anterior to farmland ownership 
affirmation. Otherwise, the detailed farmland ownership affirmation goes against construction of agricultural infrastructure and water conservancy works, agricultural scale operation and agricultural modernization. Some of the capital of rural land consolidation can come from price of construction land index commuted by newly-increased farmland from rural land consolidation. [9] The construction land index is valuable. This is why people in many places want to remove residential bases of peasants and carry out centralized residence. If newlyincreased farmland can commute a part of construction land index, local governments will immediately have the enthusiasm to carry out rural land consolidation, because they can acquire construction land index. However, the capital of rural land consolidation can come from construction land index commuted by newly-increased farmland from some rural land consolidation, instead of linking to increase or decrease of city and rural construction land. There are countless contradictions caused by the so-called exchange of homestead for apartment in many areas.

Alike the policy linked to increase or decrease, the above measures can make cultivated land in rural areas do not reduce and improve the quality of stocked farmland, solve the problem that local governments lack enthusiasm in building agricultural infrastructure.

After urban land and household registration system get effective reform and peasant-workers acquire stable residence and education, outflow population in rural areas leave home and the land can be released. That is to say, peasants can settle down in cities. They can rent house, and even afford house in the future. Their children can attend school in cities, so peasant-workers do not want to live in the countryside. Therefore, the land of peasants can be released. The government will not ask peasants to hand over lands for free in operation. After rural land consolidation is carried out, if it can commute a part of construction land index. If the index can make a profit, part of the money can be used for rural land consolidation. Besides, some money may be left. Local governments directly negotiate with peasant-workers and spend some money in buying homestead and farmland of peasants, then distribute to people who stay in the countryside originally. In this way, people staying in the countryside can enlarge scale of cultivated land. The quality of cultivated land will be improved as well. Peasants staying in the countryside will raise income. Agricultural modernization and urban-rural integration can be achieved through rural land consolidation, commuting construction land index, and then affirming the ownership.

\section{CONCLUSION}

In this way, the land system reform from the city to countryside in China can be realized gradually. It can let 400 million to 450 million peasant-workers and their family members enter service industry, manufacturing sector in 10 to 15 years and form benign urbanization and stimulate economic growth in the current society. China will have the opportunity to stride across middle-income trap. Land system reform is the only route which must be passed.

\section{REFERENCES}

[1] Tan Yongzhong, Wang Qingri, Feng Jingjun, Chen Jia, Feng Hongyan Micro Cause of Production of Urban Village Problems-Analysis on "Land Rent Residual" [J], China Land Science, 2009, 23(7): 4-8

[2] National Bureau of Statistics, 2014 Statistics Bulletin of the National Economic and Social Development, National Bureau of Statistics website

[3] Bao Haijun. Distributing the Incremental Land Value Arising from Land Expropriation in Urban-rural Fringe: Farmers' Reaction and Urban and Rural Land Acquisition Value Added Income Distribution: the Response of Farmers and Equilibrium Path [J], China Land Science, 2009, 23(7): 32-36

[4] Dang Guoying. Current Situation and Problems of Institutional Reform of Farmland in China at Present [J], Journal of Huazhong Normal University: Humanities and Social Science Edition, 2005, 44(4): 8-18

[5] Peng Yi, Wu Yuzhe. Research on Prediction of Cultivated Land Requirements in Jinyun Country on the Basis of Risk Analysis [J], China Land Science, 2009, 23(7):49-54

[6] Tao Ran, Cao Guangzhong. Mismatching of "Urbanization of Space" and "Urbanization of Population" and Policy Mix Response [J], Reform, 2008(10): 83-88

[7] Chen Zhigang, Qu Futian, Han Li. Problems of Rural Land in Industrialization and Urbanization Process: Characteristics, Causes and Solutions [J], Reform of Economic System, 2010(5): 93-98

[8] Cui Chaodong. Discussion on Path Selection of Land System Reform in Rural Urbanization of China [J], Journal of Hebei University of Economics and Business, 2011, 32(4): 35-38

[9] Zhang Yongliang. Analysis on Urbanization and Institutional Reform of Farmland [J], Journal of Northwest Agriculture and Forestry University: Social Science Edition, 2004, 4(2): 6-10 